\title{
Kehidupan Gay dalam Perspektif Interaksionisme Simbolik
}

\author{
Bayu Irawati RM, ${ }^{1 *}$ Nur Hasyim ${ }^{2,3}$ \\ ${ }^{1}$ Program Studi Magister Sosiologi, Fakultas Ilmu Sosial dan Ilmu Politik (Fisipol), \\ Universitas Sriwijaya, Palembang - Indonesia; ${ }^{2}$ Fakultas Ilmu Sosial dan Ilmu Politik, \\ Universitas Islam Negeri Walisongo, Semarang - Indonesia; ${ }^{3 R i f k a ~ A n n i s a ~ W o m e n ' s ~}$ \\ Crisis Center, Yogyakarta - Indonesia
}

\begin{abstract}
This study aims to explore gay life in Palembang using a symbolic interactionism perspective. The research applies a symbolic interactionism method to understand the behavior and social interaction of gays in their daily lives. Primary data is obtained through participatory observation and direct interviews using interview guidelines. While secondary data is gathered from many articles about homosexuals such as gay, lesbian, or LGBT. The results showed that first, gays have their own symbols both gesture and other communication types in their social lives such as in family life, intimate relationship, friendship, workplace, and in their neighborhood life. Second, gays define their sexual orientation as natural and consider themselves different from transsexuals since they do not transform their masculine identities.

Penelitian ini bertujuan untuk mengeksplorasi kehidupan gay di Palembang menggunakan perspektif interaksionisme simbolik. Penelitian ini menggunakan metode interaksionisme simbolik untuk memahami perilaku dan interaksi sosial gay dalam kehidupan sehari-hari mereka. Data primer diperoleh melalui observasi partisipatif dan wawancara langsung menggunakan pedoman wawancara. Sementara data sekunder dikumpulkan dari berbagai artikel tentang homoseksual seperti gay, lesbian, atau LGBT. Hasil penelitian menunjukkan bahwa pertama, gay memiliki simbol tersendiri baik gesture dan komunikasi dalam kehidupan sosialnya baik dalam kehidupan keluarga, kehidupan bersama pasangan gay, kehidupan pertemanan, kehidupan dengan teman kerja, dan kehidupan di lingkungan tempat tinggal. Kedua, gay memaknai dirinya sebagai perilaku seksual yang bersifat kodrati dan memaknai dirinya yang berbeda dengan waria walaupun menyukai sejenis. Perbedaan yang dimaksudkan karena gay memaknai dirinya tidak mengalami transformasi (perubahan) identitas maskulinnya.
\end{abstract}

Keywords: sexual minority; gay; symbolic interractionism; social life

*Korespondensi Penulis: Bayu Irawati RM (bayu.irawatirm@gmail.com), Program Studi Magister Sosiologi Fakultas Ilmu Sosial dan Ilmu Politik (Fisipol), Universitas Sriwijaya, Jl. Raya Palembang - Prabumulih Km. 32 Indralaya, Ogan Ilir, Sumatera Selatan 30662. 


\section{Pendahuluan}

Sejarah budaya Indonesia di beberapa tempat sudah mempraktikkan hubungan sesama jenis (homoseksual) seperti calabai dalam masyarakat Bugis, gemblak dalam kesenian Reog Ponorogo dan kebudayaan anak jawi di Sumatera Barat (Marching 2010). Meskipun homoseksual ada di beberapa kebudayaan, hubungan sesama jenis tidak dapat diterima sepenuhnya oleh masyarakat Indonesia pada umumnya. Sulitnya penerimaan homoseksual ini membuat pelakunya memilih berjalan secara underground (sembunyisembunyi) untuk menghindari intimidasi dan diskriminasi oleh masyarakat. Sulitnya penerimaan terhadap homoseksual ini memunculkan efek ketakutan dan penolakan terhadap homoseksual. Ketakutan dan penolakan ini dikenal dengan istilah homophobia (Polymenopoulou 2018).

Penolakan dan diskriminasi yang dialami homoseksual ini mendapat perhatian dan dukungan dari berbagai pihak. Seperti yang tertuang dalam Laporan Kajian Pandangan Transgender Terhadap Status Gender dan Persamaan Hak Asasi Manusia yang diadakan di empat kota, yaitu Jakarta, Bogor, Depok dan Tangerang, menjelaskan Deklarasi Hak Asasi Manusia di dalamnya menyepakati tentang kesetaraan gender, kependudukan dan HAM (UNDP dan USAID 2014). Saat ini kelompok Lesbian, Gay, Biseks dan Transgender di Indonesia, terutama gay sedang memperjuangkan haknya untuk memperoleh keabsahan identitas seksualnya, termasuk status hukum, gender, perkawinannya dengan sesama jenis, dan tuntutan untuk tidak diperlakukan diskriminatif dalam kehidupan sosial (Cho 2019; Khanis 2013). Perbedaan orientasi seksual tersebut membuat homoseksual kesulitan untuk jujur pada lingkungan sosial mereka. Kondisi tersebut menjadi permasalahan utama bagi kaum homoseksual, mereka sendiri merasakan bahwa posisinya sebagai kelompok yang dikucilkan (Boellstorff 2016).

Berbanding terbalik dengan hukum yuridis di Indonesia yang menolak mengesahkan Lesbian, Gay, Biseksual, dan Transgender (LBGT) terutama gay, akan tetapi Komnas HAM Indonesia memasukkan LBGT sebagai kelompok minoritas yang harus di hormati hak-haknya. Selaras dengan hal itu pula beberapa Peraturan Daerah (Perda) menyebutkan bahwa LBGT dianggap sebagai tindakan yang melanggar peraturan daerah. Seperti yang tertuang dalam Perda provinsi Sumatera Selatan Nomor 13 Tahun 2002 pasal 1 ayat 22 menyebutkan homoseks adalah hubungan seksual antara seorang atau lebih orang wanita dengan sesama jenis dalam wilayah Provinsi Sumatera Selatan. Selanjutnya di ayat 24 menjelaskan sodomi adalah hubungan seks melalui anus yang dilakukan oleh seorang atau lebih lakilaki terhadap orang lain, keduanya termasuk perbuatan maksiat yang melanggar ketentuan norma keagamaan, norma kesusilaan, norma adat istiadat dan norma hukum. Berbanding lurus dengan Perda provinsi, isi Perda Kota Palembang Nomor 2 Tahun 2004 juga menjelaskan hal serupa. Isi Perda Kota Palembang tersebut dijelaskan dalam pasal 1 ayat 10 dan 12, pada ayat 10 menjelaskan homoseks adalah hubungan seksual antara sesama laki-laki, dan di ayat 12 dijelaskan pula sodomi adalah hubungan seks melalui anus yang dilakukan oleh orang laki-laki. Berdasarkan Perda Kota Palembang tersebut homoseks dan sodomi termasuk perbuatan pelacuran, dengan ancaman hukuman pidana sekurang- 
kurangnya enam bulan dan denda sebanyakbanyaknya lima juta rupiah.

Menjadi seorang homoseksual terutama gay di Palembang bukanlah sesuatu yang mudah diterima, mereka harus menghadapi diskriminasi dan penolakan terhadap keberadaan mereka. Pada artikel ini, penulis memfokuskan pada bahasan tentang gay, khususnya kehidupan seorang gay di Kota Palembang. Menurut hasil penelusuran Tim Liputan Sriwijaya Post tahun 2013, fakta lapangan terkait dengan homoseksual (gay dan lesbian) banyak terjadi pada anak $\mathrm{ABG}$ (Anak Baru Gede). Anak-anak usia belasan tahun di Kota Palembang memiliki risiko penyimpangan orientasi seksual akibat pergaulan.

Kesaksian penelurusan Sriwijaya Post tahun 2013, kehidupan gay dan lesbian mudah ditemui di tempat umum. Di tempat umum tersebut mereka bebas menampakkan jati diri mereka. Komunitas lesbian di Palembang menyukai kawasan museum BKB (Benteng Kuto Besak), Kambang Iwak Kecik, sekitar Taman TVRI dan Simpang Polda. Sementara gay menyukai kawasan museum BKB, Simpang Polda dan mall. Fakta lainnya dari hasil penelurusan Sriwijaya Post banyak anak yang masih duduk di bangku SMP menjadi gay, dengan iming-iming "dugem" gratis, anak-anak tersebut mau diajak bersenang-senang. Gay ABG dapat berperan menjadi pria (top) dan wanita (bottom), kesepakatan posisi tersebut tergantung kepada gay yang lebih tua untuk mengarahkan ABG tersebut. (Tim Liputan Sriwijaya Post 2013).

Meskipun gay rentan terhadap perlakuan diskriminasi dan gay juga dianggap melanggar norma-norma yang berlaku dan perbuatan menyimpang, seorang gay ataupun komunitasnya tetap ada dan berkembang di Kota Palembang. Hal ini menarik untuk diketahui dan diteliti, mengingat norma keagamaan, norma kesusilaan, norma adat istiadat dan norma hukum yang berlaku di Kota Palembang menyebutkan bahwa homoseksual-gay termasuk tindakan maksiat dan pelacuran.

Kajian tentang kehidupan gay di Indonesia telah banyak dilakukan oleh para peniliti di antaranya studi yang dilakukan oleh Boellstorff (2010). Profesor Antropologi pada Stanford University dan University California itu meneliti kehidupan gay muslim di Indoensia. Melalui kajian etnografi Boellstorff memotret bagaimana gay muslim memahami hubungan antara agama dan seksualitas. Ia menemukan dilema yang dihadapi gay muslim antara dosa dan pandangan bahwa hasrat kepada sesama laki-laki sebagai berasal dari tuhan atau bersifat ilahiah.

Diniati (2018) meneliti konstruksi sosial mahasiswa gay di Bandung. Dengan metode studi kasus, Diniati mengkaji pengalaman 4 mahasiswa gay di kota kembang itu. Penelitian ini menemukan bahwa faktor dominan yang mempengaruhi informan menerima dirinya sebagai gay adalah adanya kebutuhan psikologis dan sosial serta hasrat atau orientasi seksual.

Berbeda dengan dua penelitian sebelumnya, Adriani, Anggai, dan Pradoponingrum (2017) mengkaji bagaimana seorang gay mengungkap diri bahwa dirinya adalah seorang gay. Ada dua kelompok yakni kelompok yang mengakui secara terbuka identitas sosialnya sebagai gay dan kelompok yang menutuskan untuk menyembunyikan identias seksualnya. Ketakutan akan menge- 
cewakan dan penolakan keluarga menjadi alasan mengapa kelompok kedua ini menyembunyikan identitas seksualnya.

Penelitian lainnya dilakukan oleh Pranata (2015) terhadap perilaku dan realitas sosial gay di Kota Samarinda, menemukan perilaku tertutup dan eksklusif. Perilaku ini dilatari oleh kekhawatiran akan reaksi negatif masyarakat yang menganggap gay sebagai perilaku menyimpang.

Penelitian ini merupakan bagian dari perbincangan tentang gay di Indonesia yang sudah dimulai oleh peneliti sebelumnya. Penelitian ini mengupas realitas kehidupan gay dalam memaknai dirinya dan kehidupannya di Palembang.

Penelitian ini menggunakan teori interaksionisme simbolik George Herbet Mead. Menurut Mead (dalam Ahmadi 2008) mengemukakan bahwa inti dari teori interaksionisme simbolik adalah tentang diri (self), Mead menganggap bahwa konsep diri yang berasal dari interaksi sosial individu dengan orang lain.

Penelitian ini menggunakan metode interaksionisme simbolik dilakukan dengan cara pengamatan serta wawancara dengan seorang gay yang tinggal di Palembang. Informan kunci dalam penelitian ini berinisial BP dan dibantu dengan beberapa informan pendukung. Selain itu ada beberapa informan. Penelitian ini mengambil rentang waktu dari bulan Februari sampai dengan bulan April 2019, dengan durasi waktu kurang lebih 3 (tiga) bulan.

Selanjutnya tujuan penelitian ini adalah untuk mengeksplorasi dan menganalisis kehidupan gay di Palembang. Kehidupan sosial seorang gay itu meliputi kehidupannya di dalam keluarga, bersama pasangan, di tempat tinggal, di lingkungan kerja dan kehidupan sosial pertemanan. Penelitian ini juga ingin mengetahui makna gay bagi kehidupan yang dijalaninya.

\section{Interaksi Sosial Kaum Gay}

Haryanto dan Nugrohadi (2011:213-15) memaparkan kehidupan sosial manusia dimulai dengan relasi sosial manusia, relasi tersebut mempunyai bentuk konkret sesuai dengan nilainilai sosial dalam suatu masyarakat. Salah satu kunci kehidupan sosial adalah interaksi sosial, interaksi sosial merupakan syarat utama terjadinya aktivitas-aktivitas sosial. Interaksi sosial merupakan hubungan dinamis, mengutip Gillin dan Gillin (dalam Soyomukti 2010:315) menegaskan interaksi sosial merupakan hubunganhubungan sosial yang dinamis yang menyangkut hubungan antara orang perorang, antara kelompok-kelompok manusia, antara perorangan dan kelompok manusia.

Interaksi sosial merupakan kunci semua kehidupan sosial, karena tanpa adanya interkasi sosial maka tidak ada kehidupan bersama. Dalam interaksi sosial ini seseorang mempunyai tujuan dimana seseorang bertindak berdasarkan pencapain tujuan mereka. Kehidupan sosial manusia lekat dengan lingkungan sosial, Arifin (2015:1) mengemukakan lingkungan sosial ditandai dengan individu yang saling berinteraksi atas dasar status dan peranan sosial yang diatur oleh seperangkat norma dan nilai atau tatanan sosial. Manusia sebagai mahluk individu dan mahluk sosial merupakan gabungan dari aspek ind ividu sebagai perwujudan dirinya sendiri dan mahluk sosial sebagai anggota kelompok ataupun 
masyarakat. Oleh karena hal tersebut setiap perilaku yang oleh individu akan mempengaruhi sesorang lainnya bahkan dalam kelompok sekali pun. Lingkungan sosial dapat berupa keluarga, teman sejawat, pasangan, relasi di tempat kerja, dan lingkungan di sekitar tempat tinggal.

Tidak terkecuali kehidupan yang dijalani homoseksual-gay yang tidak lepas pula dari lingkup hubungan sosial dan interaksi sosial. Meskipun hubungan sesama jenis menjadi hal wajar di sebagian kalangan di Indonesia akan tetapi resistensi homophobia terus bergulir. Hal itu juga sama yang dialami oleh gay di Palembang, homophobia masyarakat terhadap gay memberikan beban tersendiri bagi mereka. Di luar orientasi seksual mereka penampilan seorang gay di Palembang terlihat seperti laki-laki pada umumnya dan berprilaku seperti tidak mencerminkan orientasi seksual mereka. Akan tetapi keadaan ini kontradiktif jika gay tersebut bertemu dengan pasangan sesama jenisnya, mereka saling menunjukan sikap romantisme pasangan. Perilaku mereka berubah-ubah ketika bersama pasangan gaynya, ketika bersama teman yang bukan gay dan ketika bersama keluarga.

Dengan upaya penyusuaian diri dengan lingkungan sekitar sangat perlu di lakukan oleh seorang gay, hal ini untuk menghindari sikap diskrimisasi dan homophobia dari lingkungan sekitarnya. Sikap penyesuaian diri seorang gay di lingkungan sosial mereka adalah bentuk dari $\mathrm{Me}$ dalam diri menurut Mead. Me adalah generalisai dari sekumpulan sikap orang lain yang mempengaruhi indiviu untuk bertindak. $I$ dalam diri mereka adalah subjek awal dari respons keadaan sosisial di sekiling mereka. Homophobia adalah hasil ketidak sesuaian dari norma dan aturan sosial yang berlaku di tempat tertentu, I menerimanya sebagai stimulus yang diterima oleh diri selanjutnya diterima oleh diri untuk berpikir dan mencari sikap atas tindakan tersebut. Dari I mengelolahnya menjadi $\mathrm{Me}$ sebagai respons diri hasilnya menjadi respons diri yang berubah-ubah sesuai dengan keadaan di sekelilingnya (Ahmadi 2008; Ritzer 2009; Ritzer dan Douglas 2011).

Gay di Palembang lebih cenderung menutup diri tentang identitas seksual mereka, mereka memilih bersembunyi di balik maskulinitas yang tampilkan. Tekanan sosial berupa homophobia yang berkembang di masyarakat serta minimnya informasi tentang homoseksual memberi pengaruh terhadap presentasi diri seorang homoseksual. Sebagian masyarakat kita dapat menerima keberadaan waria, akan tetapi tidak dengan pasangan sesama jenis. Gay di Palembang lebih banyak mengelabui identitas mereka dengan gesture yang mereka tampilkan, mereka menciptakan komunikasi sendiri melalui gesture dan simbol yang hanya dimengerti oleh mereka sendiri.

Komunikasi antar gay lewat gesture dan simbol yang hanya dimengerti oleh mereka, seperti dengan saling memandang sesamanya, mereka akan mengetahui satu sama lain kemudian mereka akan berkenalan. Saling berpandangan dan saling menangkap "sinyal" adalah cara gay untuk mengetahui jati diri satu dengan lainnya, cara seperti ini dikenal dengan istilah "gay-dar" (gay radar). Jika kebanyakan gay dicirikan dengan sebuah penanda tidak dengan gay di Palembang. Mereka lebih menutupi identitas mereka guna melindungi diri mereka sendiri dari lingkungan 
sekitar dan termasuk keluarga. Meskipun gay sendiri tidak secara terbuka menunjukan identitas seksual mereka, tetapi gay itu sendiri bisa mengetahui bahwa seseorang itu gay atau bukan melalui tatapan mata mereka, gay-dar ini juga merupakan salah satu bentuk interaksi sesama gay sekaligus penanda identitas seksual mereka.

Meskipun gay tersebut bersembunyi di balik kebenaran identitas seksual mereka, faktanya gay tetap menjalani kehidupannya dengan cara mengelabui lingkungan sekitar hal ini diungkapkan oleh Garfinkel. Garfinkel (Denzin dan Lincoln 2009:337) memadang fakta sosial dari sudut pandang etnometodologis, yaitu fakta sosial tercipta karena adanya tindakan interpretatif dari setiap anggota masyarakat-aktivitas yang menjadi wahana bagi aktor untuk memproduksi dan mengorganisasikan kondisi dalam kehidupan sehari-hari itu sendiri. Setiap lingkungan sosial yang jalani gay tersebut berbeda-beda tergantung kepada aktivitas dan respons yang dihadapi gay tersebut.

Stigma sosial mendeskreditkan seorang gay ataupun komunitasnya, gay tetap ada dan berkembang di Palembang. Penulis menemukan gay yang menjalani kehidupannya dengan bersembunyi di balik kebenaran identitas seksualnya. Identitas seksual seorang gay yang berbeda ini juga memberikan pengaruh pada presentasi diri seorang gay di Palembang. Menjalin hubungan sesama jenis di Palembang tidaklah mudah, di mana adat, norma dan nilai-nilai yang ada tidak memberikan ruang bagi homoseksual. Presentasi diri seorang gay ini juga mempengaruhi interaksi sosial mereka baik, di lingkungan masyarakat pada umumnya dan juga presentasi pada kelompok gay itu sendiri. Penolakan masyarakat awam terhadap gay yang masih terasa asing di Palembang sehingga mereka sendiri harus memperjuangkan identitas diri di tengah diskriminasi masyarakat kota Palembang.

\section{Kehidupan Gay dalam Keluarga}

Keluarga merupakan suatu sistem sosial terkecil (Lewis 2016; Satya Yoga, Suarmini, dan Prabowo 2015). Keluarga adalah lingkungan pertama yang dihadapi BP setiap harinya dari kecil hingga dewasa tinggal bersama keluarganya. Keluarga merupakan lingkungan paling terdekat sekaligus sensitif, oleh karena itu membuat BP sangat hati-hati menyimpan rapat rahasia kehidupannya. Bagi para gay rumah adalah menjadi tempat identitas seksual gay harus disembunyikan, untuk mengungkapakan orientasi seksual BP sangat sulit. Menurut Cramer dan Roach (1988) pengungkapan diri terhadap orang tua terasa sulit karena adanya perasaan takut bahwa ada nada respons yang tidak terduga, seperti adanya penolakan dari orang tua.

BP tinggal di lingkungan padat penduduk terletak di pinggiran sungai Musi yang dengan perjalanan sekitar 45 menit pusat dari kota, rumah panggung dengan luas $10 \times 15 \mathrm{~m}$ terbuat dari papan menjadi tempat tinggal BP dan keluarganya. BP tinggal bersama ayah, ibu serta kelima saudaranya, dan kelima saudaranya adalah laki-laki. Di dalam keluarga, BP diperlakukan superior di antara adik-adiknya, perlakuan istimewa orang tua BP terhadap dirinya membuat BP merasa dimanja oleh kedua orang tuanya. Sebenarnya BP merupakan anak kedua akan tetapi kakak perempuannya meninggal di usia dini. Semenjak meninggalnya kakak perempuan BP perhatian orang tuanya terfokuskan pada BP. 
Salah satu perlakuan istimewa yang diberikan oleh orang tua BP seperti, sepulang dari kerja dari pasar, ayah BP suka membelikan makanan kesukaan BP sedangkan adik-adiknya jarang diperlakukan seperti itu. Di rumah BP lebih banyak menghabiskan waktunya di dalam kamar, aktivitas yang ia lakukan seperti nonton film, chatting, tidur sesekali membaca koran.

BP lebih suka menghabiskan waktunya di dalam kamar selepas pulang kerja, keluar dari kamar hanya untuk makan, ke kamar kecil dan shalat. BP tidak banyak berinteraksi dengan kelima saudara lainnya, dengan alasan untuk menghindari keributan di antara mereka. Meskipun begitu, BP turut membantu ekonomi keluarga dan biaya sekolah adik-adiknya. BP lebih nyaman berada di dekat ibunya daripada ayahnya, kesan ayah bagi BP adalah sosok yang keras dan pelit terhadap keluarga. Selepas SMA BP mulai memahami keadaan dirinya yang berbeda, BP mulai mengerti jika dirinya adalah seorang homoseksual-gay. BP mulai menutup diri dari lingkungan rumah sekitarnya, hal ini dilakukan untuk menyembunyikan identitas seksualnya. BP merasa tidak nyaman dengan keadaan dirinya, oleh karena itu BP mulai mencari kenyaman yang ia inginkan seperti mencari pasangan sejenis melalui media sosial. BP termasuk seseorang yang introvert dikenal kurang bersosialisasi dengan tetangga sekitar rumahnya, berbeda dengan kedua orang tua BP yang masih berbaur dengan tetangga. Sikap BP yang ditampilkan dalam kesehariannya juga tidak menujukan bahwa BP berorientasi seksual berbeda dengan sifat alami manusia, hal ini juga di tuturkan BP.

Dalam pengasuhan anak di dalam keluarga BP lebih dimanja daripada adik-adiknya, seperti dalam hal beban kerja di rumah menurut keterangan uwak BP, BP lebih dimanja jarang melakukan pekerjaan rumah, pekerjaan rumah lebih banyak dilakukan oleh ibunya mulai dari masak, bersih-bersih rumah sampai mencuci pakaian BP, ketika BP ingin membantu orang tuanya menolak, ibu dan ayah BP lebih memanjakan BP. BP termasuk anak yang ingin dekat bersama keluarga, terutama ibunya. Beberapa kali BP ditawari pekerjaan di luar Palembang, BP menolaknya, yang menjadi alasan BP adalah tidak ingin menjauh dari ibunya.

Seperti anak pada umumnya BP turut andil dalam menghidupi keluarganya seperti ikut membiayai sekolah adik-adiknya serta membantu memenuhi kebutuhan dapur ibunya. Pekerjaan tetap, finansial dinilai cukup dan usia yang matang mendatangkan beban tersendiri bagi BP seperti munculnya tuntutan untuk menikah. Menikah disebagian masyarakat bukan lagi menjadi sebuah pilih akan tetapi sudah menjadi tuntutan dalam tatanan sosial terkecil. BP kerap kali mendapat pertanyaan tentang keinginan untuk menikah, ditambah lagi BP tidak pernah membawa teman perempuan (pacar) untuk diperkenalkan kepada orang tuanya, akan tetapi hal itu selalu dibantah BP. Tidak terlintas dalam pikiran BP akan menghabiskan hidupya dengan membohongi diri dan keluarga hanya karena memenuhi tuntutan keluarga untuk menikah dengan perempuan. BP sendiri mengakui bahwa dirinya tidak mempunyai hasrat seksual terhadap perempuan, pernah sekali waktu BP ingin memunculkan rasa suka terhadap perempuan akan tetapi hal itu tidak berhasil.

BP kerap membawa teman laki-lakinya pulang ke rumah dan menginap di rumah BP, 
tanpa curiga orang tua BP mempersilahkan pasangan BP untuk menginap dirumah BP. Orang tua BP sendiri menganggap yang dibawa BP ke rumah itu adalah sekedar teman biasa. Jika BP bersama pasangannya sedang di rumah orang tua BP, BP lebih sering menutup pintu kamarnya berbeda jika tidak sedang bersama pasangannya, BP lebih sering membiarkan pintu kamarnya terbuka sehingga aktivitas yang dilakukan BP di dalam kamar diketahui oleh orang tuanya.

Perbedaan sikap yang ditunjukan BP saat bersama pasangannya di dalam rumah BP sempat menimbulkan rasa curiga ibu BP. Ibu BP sendiri mempertanyakan teman-teman BP yang diajaknya untuk menginap di rumah. BP memang terkadang membawa teman laki-laki yang berbeda, akan tetapi BP memberikan alasan bahwa laki-laki yang datang dan menginap itu hanya sekedar temannya di kantor atau teman di kampusnya dulu.

Sebagai anak BP sering kali berbohong tentang dirinya terhadap keluarganya, kadang merasa berdosa dengan perilaku dirinya, akan tetapi dorongan rasa suka dan hasrat terhadap laki-laki sangat sulit terelakan dalam dirinya. Sikap BP yang menutupi keadaan orientasi seksualnya merupakan tindakan hasil dari respons di sekitarnya. Sikap BP mempresentasikan diri seperti lelaki normal dan memegang teguh norma agama seperti menjalankan ibadah, tidak membawa teman perempuan non-mahram kecuali calon isteri, berpenampilah seperti laki-laki normal serta menghindari atributgay dalam penampilan BP.

\section{Kehidupan Bersama Pasangan Gay}

Kehidupan gay secara tidak terang-terangan membuat mereka harus bisa menyesuaikan diri dengan keadaan sekitarnya agar tidak menimbulkan kecurigan terhadap tingkah laku mereka. Kehidupan gay banyak dihabiskan di ruang privasi seperti rumah pribadi, kontrakan, kamar hotel dan kos-kosan. Apabila gay muncul di ruang publik mereka memilih tempat yang menghindarkan mereka dari tindakan diskriminasi, beberapa tempat yang mejadi favorit bagi para gay ini seperti tempat karaoke, mall, dan club malam.

Banyak hal yang membelenggu keberadaan gay seperti munculnya peraturan daerah di Kota Palembang. Didalam Peraturan Daerah (Perda) Provinsi dan Perda Kota Palembang tertuang jelas menolak keberadaan homoseksual, ditambah pula homophobia yang berkembang di masyarakat mendeskreditkan keberadaan homoseksual. Fenomena gay di Palembang sendiri tidak lepas dari latar belakang lingkungan sosial, gaya hidup dan pola asuh orang tua. Dari hasil pengamatan penulis, orientasi seksual yang bersifat sama tersebut muncul berdasarkan pengalaman seorang gay baik karena rasa sakit hati dan kecewa yang mendalam terhadap lawan jenis, sikap dominan seorang orang tua dalam mengasuh anak-anaknya, bahkan ada yang menujukkan menjadi seorang gay beralasan materi.

Dalam beberapa kesempatan peneliti sempat tinggal bersama BP, di mulai dari kegiatan pagi hari, BP bangun menjalankan ibadah shalat Subuh, setelahnya BP terkadang mengaji atau hanya membuka HP lalu tidur lagi. Sekitar satu jam kemudian BP bangun lalu mempersiapkan diri untuk pergi bekerja pagi, di sela-sela persiapan kerja BP terbiasa berkomunikasi dengan pasangan sejenisnya, mereka biasa menggunakan WhatsApp sebagai media untuk chatting atau 
video call. Kegiatan pasangan gay ini ketika pagi hari mereka video call. Yang diobrolkan hanya sebatas jadwal kegiatan masing-masing, pembicaraan mereka terlihat seperti teman biasa tidak lebih dari itu, dan memang hal itu yang mereka inginkan, agar tidak terlihat "aneh" bagi orang-orang di sekitar mereka. Jam kerja BP yang per-shift membuat BP lebih leluasa untuk membagi waktunya untuk dirinya, keluarga, pasangan dan teman-temannya.

Layaknya pasangan heteroseksual pada umumnya, perlakuan seperti sikap romantisme, manja, perlakuan saling menyayangi kerap kerap ditunjukan mereka ketika sedang bersama BP cenderung ekspresif terhadap pasangannya seperti BP lebih cenderung manja dengan pasangan, seambil menonton TV terkadang BP tidur di pangkuan pasangannya, tak segan-segan BP memeluk pasangannya, sikap romantime tergambar jelas dalam hubungan mereka. Begitu pula dengan pasangan BP juga terlihat nyaman dengan sikap BP kepadanya. BP lebih nyaman menjalani hubungan dengan laki-laki, menurutnya hal tersebut dapat membangkitkan hasrat seksualnya, menurut BP seseorang bisa menentukan pilihan hidup yang dijalani meskipun hal tersebut melanggar aturan yang berlaku.

\section{Kehidupan dengan Teman Kerja}

Sudah sekitar setahun lebih BP bekerja di bidang jasa, di mana tempat ia bekerja di bidang pelayanan. Sebagai orang pertama yang menghadapi pelanggan tentunya membuat BP harus tampil menarik di hadapan pelanggan. Pekerjaan BP juga membutuhkan waktu dan tenaga ekstra untuk menghadapi pelanggan yang berbedabeda, akan tetapi BP dan timnya dapat bekerja dengan baik. Salah seorang rekan kerja BP, MN menuturkan selama bekerja dengan $\mathrm{BP}, \mathrm{BP}$ dikenal pribadi yang ceria dan ramah, terkadang terkesan bocor bagi teman-teman lainya. Pertama mengenal BP, BP terkesan pribadi yang pendiam akan tetapi hal itu berbeda ketika sudah mengenalnya lebih jauh. Bagi rekan-rekan kerja lainnya BP dinilai termasuk karyawan yang cekatan, perhatian dengan sesama dan termasuk karyawan yang pintar. BP dikenal dengan pengetahuan yang luas, apabila diajak berdiskusi atau berbincang sesuatu BP akan cepat memahaminya.

Salah satu teman kerja BP mengetahui tentang orientasi seksual BP, hal itu tidak membutanya menjauhi BP, dalam lingkungan pekerjaan mereka seorang gay adalah hal yang tidak bisa dihindari, BP bukan satu-satunya seorang gay di tempat kerja tersebut, ada di antara karyawan lainnya yang juga merupakan seorang gay. Meskipun gay menjadi kelompok minoritas, mereka tidak mengalami diskriminasi atau bullying dari rekan kerja lainnya. Rekan kerja lainnya memaklumi dengan kondisi seorang gay yang memang berbeda dengan mereka. Pekerjaan BP di bidang pelayanan dimana BP akan bertemu dengan banyak orang, hal ini menguntungkan BP dan teman sesama gay lainnya, karena mereka dapat sekaligus mencari teman kencan.

Di sela-sela saat bekerja membuat BP dan temannya sesama gay dapat mencari temen kencan, mereka suka rebutan melayani konsumen apabila ada dinilai ganteng. Dari padangan mata yang mereka yang bermakna kode kemudian berujung pada sentuhan tangan lembut kepada orang yang dituju untuk mempertegas 
ketertarikan dan sebuah ajakan. Apabila seseorang itu gay kan maka akan merespons kode yang mereka isyaratkan, seperti membalasnya dengan menatap kembali dan merespons sentuhan. Setelah itu biasanya akan berlanjut pada perbincangan dan bertukar nomor telepon. Meskipun mereka mengambil kesematan di selasela bekerja, tidak membuat BP dan MN mengabaikan pekerjaan mereka, karyawan lain menilai tindakan yang dilakukan BP dan MN biasa saja.

Rekan kerja BP juga menilai meskipun BP seorang gay, BP tetap menjaga ibadahnya seperti shalat lima waktu, puasa sunnah dan di saat-saat tertentu BP suka membaca berita. Rekan lainnya juga mengatakan bahwa BP nyaman diajak curhat ataupun bercerita, sosok BP yang terbuka dan mau mendergarkan orang lain membuat teman kerja BP lainnya mereasa nyaman ketika bersama BP. Kedekatan BP dan teman kerjanya tidak hanya terjadi di tempat kerja saja akan tetapi di luar jam kerja mereka juga sering berkumpul dan jalan, seperti mencari makanan, nonton bioskop, atau sekedar duduk di kafe. BP sangat bersyukur mempunyai teman kerja yang mengerti keadaan dirinya dan tidak berbuat diskriminasi terhadap dirinya.

\section{Kehidupan di Lingkungan Tempat Tinggal}

Tinggal di lingkungan yang padat penduduk dan berlokasi di pinggiran sungai Musi menjadi tempat tinggal BP dan keluarganya. Rumah semi permanen dengan luas $10 \times 15 \mathrm{~m}$, menjadi tempat keseharian BP dan keluarganya menjalani kehidupan. Di sekitar lingkungan BP tinggal terdapat kebiasaan warganya berkumpul, entah sekedar bercerita dengan tetangga atau bahkan berkumpul untuk bermain kartu remi. Perempuan dan laki-laki memainkan permainan yang sama, kebiasaan seperti ini membuat BP merasa tidak nyaman dengan lingkungan sekitar tempat tinggal. Di lingkungan sekitar rumah BP, BP dikenal pribadi pendiam, jarang bergaul dengan tetangga apabila berinteraksi pun hanya sekedarnya. BP menjaga jarak dengan lingkungan sekitar rumahnya hal ini didasari ketidak nyaman BP dengan siklus lingkungan di sekitar tempat tinggalnya, menurut BP lingkungan sekitarnya ingin tahu terhadap kehidupan para tetangganya, selain hal itu kebiasaan mengunjing membuat BP mengindari interaksi dengan tetangga sekitarnya.

Melalui penuturan uwak BP yang tinggal berhadapan dengan rumahnya, menuturkan setelah memasuki fase kuliah BP, lebih suka berada di rumah dan jarang pula terlihat membawa temannya pulang ke rumah. Sesekali ia membawa teman laki-laki, sedangkan teman perempuan tidak pernah. Hal ini berbeda ketika BP masih sekolah, semasa masa sekolah BP masih suka main kumpul bersama anak-anak lainnya, jika ada acara hajatan tetangga BP masih suka datang, teman-teman sekolahnya pun terkadang berkumpul di rumah BP untuk mengerjakan tugas sekolah. Pada fase kuliah dan kerja BP cenderung lebih suka berada di dalam rumah, interaksi dengan tetangga sekitarnya berkurang, selian itu BP terlihat jarang membawa temanteman kuliahnya ke rumah.

Terkadang sesekali BP membawa teman lakilakinya pulang ke rumah, ia mengenalkan teman laki-lakinya kepada keluarga sebagai teman biasa. Tidak muncul kecurigaan di keluarga BP terhadap teman yang dibawa BP ketika pulang ke rumah, sikap BP dan pasangannya biasa saja tidak 
mencerminkan sepasang kekasih. Ibu BP sebenarnya sudah menaruh curiga kepada BP tentang kelainan seksual BP, akan tetapi ibu BP tidak mengungkapkannya secara gamblang. Kecurigaan itu muncul ketika BP lebih suka membawa teman laki-laki pulang ke rumah dan belum pernah mnegenalkan teman perempuan kepada keluarganya. Meskipun begitu ibu BP tetap menerima anaknya dan percaya bahwa anaknya dapat berubah suatu ketika.

\section{Makna Kehidupan Gay}

Pengalaman masyarakat tentang gay masih sangat minim ditambah lagi dengan konstruksi sosial masyarakat selama berabad-abad memaksakan heteronormativitas atau norma-norma orientasi seksual hetero sebagai satu-satunya kebenaran, tidak heran orientasi homoseksual dan lainnya, dianggap menyimpang, abnormal, dan tidak wajar. Bahkan, tidak sedikit orang menstigma mereka sebagai pendosa, terlaknat, penderita penyimpangan seksual, dan penyakit turunan menular. Walaupun demikian, ditemukan juga sebagian kecil masyarakat memandang homoseksual sebagai normal dan wajar, bahkan cenderung menganggap "sakral", seperti dalam beberapa kebudayaan yang telah dijelaskan.

Meskipun demikian gay tetap mempertahankan eksistensi diri sebagai pernyataan bahwa mereka ada dan merupakan bagian dari kehidupan sosial masyarakat. Perjuangan eksistensi diri kaum gay sendiri bertujuan melawan diskriminasi yang selama ini mereka hadapi. Bukan pekerjaan mudah bagi gay sendiri memperjuangkan keberadaan mereka, tentu ada hal yang melatarbelakangi hal tersebut. Penolakan atas kehadiran seorang gay baik didalam keluarga dan masyarakat membuat kehidupan seorang gay terasa penuh tantangan, bagaimana tidak mereka harus menghadapi situasi sosial yang berubah setiap waktu. Misal di dalam keluarga BP sendiri harus menghadapi tekanan menikah dari orang tuanya, mengharapkan BP dapat seperti kebanyakan laki-laki dewasa lainnya. Contoh lainnya ketika BP menghadapi lingkungan masyarakat di sekitar BP tinggal, di mana lingkungan tersebut para ibu-ibu lebih suka mengurusi kehidupan tetangga lainnya dari pada kehidupan sendiri

Kehidupan sosial yang dijalani BP baik itu di dalam keluarga, lingkungan tempat tinggal, dengan teman kerja ataupun dengan teman lainya dan dengan pasangan tentunya mempengaruhi sikap BP yang menyesuaikan dengan keadaan yang dihadapinya. Meskipun terasa sulit awalnya untuk menutupi diri dengan kebohongan, akan tetapi BP dapat menjalani kehidupannya sebagai seorang gay. Bagi BP, gay adalah pilihan hidup seseorang untuk menjalaninya dan bagaimana seseorang itu nyaman dan bahagia atas pilihan hatinya. BP menolak apabila dikatakan gay itu adalah waria, tentu saja berbeda antara waria dan gay. Bagi BP gay adalah seorang laki-laki yang menyukai sesama laki-laki tanpa adanya transformasi atau perubahan bentuk tubuh pada seorang gay, sedangkan waria adalah seorang laki-laki yang merubah hampir keseluruhan atribut maskulinitas di dalam dirinya.

Seorang gay tetap laki-laki dan memilih pasangannya adalah sesama jenis (laki-laki), hal ini berdasarkan rasa suka, nyaman dan dorongan seksual yang tertuju pada laki-laki saja, tentunya tindakan ini dilakukan dengan kesadaran. BP menyadari seorang homoseksual-gay tidak me- 
miliki tempat dalam tatanan sosial masyarakat Palembang, stigma sosial yang terbangun atas seorang gay adalah seseorang yang sakit, dapat menyebabkan penyakit mematikan, seorang gay dapat menular apabila berteman dengan mereka, selain itu seorang gay pantas mendapatkan diskriminasi dan kekerasan fisik dari kalangan heteroseksual. Tidak dipungkiri bahwa ada beban tersendiri bagi BP menjadi seorang gay, dalam agama Islam seorang homoseksual terancam dosa besar dengan neraka ancamannya, dalam lingkungan sosial seorang gay dipandang seseorang yang sakit dan menular, hal-hal seperti ini memberikan beban bagi BP. Hal-hal di luar dalam diri BP memberikan pengarauh atas sikap dan presepsi seorang gay.

Situasi yang dihadapi BP di luar dirinya memberikan timbal balik pada diri BP untuk bersikap, interaksionisme simbolik yang terjadi antara BP dan kehidupan sosial yang ia jalani memungkinkan suatu proses membentuk dan mengatur perilaku orang lain dengan mempertimbangkan feedback dari orang lain. Tidak mustahil pengaruh dari luar seperti adat, norma, bahkan hukum agama memberikan sudut pandang lain mengenai arti gay bagi BP.

Terbersit arti gay bagi BP adalah seseorang yang sakit, seseorang yang menyimpang dari proses alamiah manusia. Ada rasa BP ingin juga normal seperti orang lain, dapat menjalani kehidupan seorang heteroseksual: memiliki pasangan dari lawan jenis, memiliki keluarga, dan juga terhindar dari diskriminasi dan kekerasan fisik. BP menyadari menjadi seorang gay di Palembang sangat sulit untuk bertahan, BP melihat bahwa seorang lesbian dan waria lebih dimaklumi dan diterima dari pada seorang gay. Perempuan yang berpenampilan maskulin dianggap biasa saja, lebel tomboy dimaklumi dan mungkin masyarakat berpikir perempuan tomboy hanyalah masalah perilaku bukan masalah orientasi seksual. Sedangkan waria, kebanyakan waria di Palembang bekerja di salon, menjadi make up artis dan mengamen, tempat-tempat seperti itu sering dikujungi masyarakat dan pada akhirnya mereka pun memaklumi keadaan waria tersebut.

Gay mendapatkan sorotan lebih dari pada seorang lesbian, padahal keduanya merupakan penyimpangan orientasi seksual. Umumnya orang akan menilai perilaku perempuan bergandengan tangan dengan perempuan, dan berciuman pipi merupakan hal wajar apabila dilakukan oleh perempuan, berbanding terbalik apabila hal tersebut dilakukan oleh laki-laki, masyarakat menilai hal tersebut tidak wajar dan dapat menjadi bahan cemoohan orang lain. Gay identik dengan penyakit, dosa dan kelainan jiwa, hal ini membuat gay sulit menyesuaikan diri dengan lingkungan mereka akhirnya mereka hidup dalam kepura-puraan.

BP mengetahui bahwa pandangan lain seorang gay adalah orang yang sakit dan harus disembuhkan, BP juga mengetahui bahwa gay adalah sesuatu yang menyimpang dari kodrati seksual manusia. Secara alamiahnya seorang lakilaki berpasangan dengan perempuan, akan tetapi dalam diri BP tidak mampu melawan dorongan rasa suka dan nafsu kepada laki-laki, kontradiksi terus bergulir dalam diri BP antara naluri suka kepada laki-laki dan tekanan dari norma sosial dimasyarakat yang menolak pasangan sesama jenis. 
Kesulitan dalam diri BP untuk menyukai perempuan terutama hal tersebut berkaitan dengan dorongan seksual, tekanan nafsu dalam diri BP hanya muncul ketika bersama laki-laki. Demartoto (2010) menjelaskan pengalaman psikologis semasa hidup, masa kanak-kanak, hubungan dengan orang lain seperti keluarga. Asumsi seseorang tentang seksualitas dan perilaku dipengaruhi oleh lingkungan keluarga, pengalaman mereka dan perasaan mereka sendiri. Perasaan terhadap seks pada mulanya dibentuk oleh nilai-nilai keluarga, kemudian perasaan ini dapat dipengaruhi dan dibentuk oleh pengalaman yang menyenangkan dan tidak menyenangkan tentang seks dan juga membentuk pilihan mereka pada kegiatan seks dan pasangan seksnya.

Pengaruh norma sosial dan menganggap diri sendiri adalah orang yang sakit BP mengalami kekecewaan dalam diri menyebabkan BP mengalami setres yang ia alami, stress yang BP alami sempat membuat BP ingin bunuh diri.

Bagaimanapun juga seorang gay tetap mempertahankan eksistensi diri sebagai pernyataan bahwa mereka ada dan merupakan bagian dari kehidupan sosial masyarakat. Perjuangan eksistensi diri kaum gay sendiri bertujuan melawan diskriminasi yang selama ini mereka hadapi. Bukan pekerjaan mudah bagi gay sendiri memperjuangan keberadaan mereka, tentu ada hal yang melatarbelakangi hal tersebut. Meskipun seorang gay dianggap menyipang, orang yang sakit dan harus disembuhkan, bagi seorang gay identitas seksual merupakan sebuah pilihan hidup seseorang yang tidak dapat dicampuri oleh orang lain bahnkan aturan yang berlaku. Setiap gay mempunyai makna yang berbeda dengan orientasi seksualnya, bagi seorang $\mathrm{BP}$, gay merupakan suatu kenyaman seseorang dengan identitas seksualnya meskipun hal tersebut sangat berbenturan dengan segala sesutau yang berada disekeliling mereka.

BP menolak apabila dikatakan gay itu adalah waria, tentu saja berbeda antara waria dan gay. Bagi BP gay adalah seorang laki-laki yang menyukai sesama laki-laki tanpa adanya transformasi atau perubahan bentuk tubuh pada seorang gay, sedangkan waria adalah seorang lakilaki yang merubah hampir keseluruhan atribut maskulinitas didalam dirinya. Seorang gay tetap laki-laki dan memilih pasangannya adalah sesama jenis (laki-laki), hal ini berdasarkan rasa suka, nyaman dan dorongan seksual yang tertuju pada laki-laki saja, tentunya tindakan ini dilakukan dengan kesadaran.

\section{Kesimpulan}

Mead membagi interaksionisme simbolik menjadi dua tingkatan yaitu non-interaksionisme simbolik dan interaksionisme simbolik. Dalam non-interaksionisme simbolik, manusia merespons secara langsung gesture atau tindakan dari orang lain. Sementara dalam interasi simbolik, manusia menginterpretasi gesture dan tindakan berdasarkan makna yang di hasilkan dari interpretasi gay-dar adalah cara yang digunakan seorang gay untuk mengetahui gay lainnya terhadap gay yang belum terdektesi disekeliling mereka, respons langsung dari individu lainnya merupakan non-interaksionisme simbolik. Selanjutnya respons balik berupa tatapan yang sama bahakan lebih merupakan tindakan yang dihasilkan dari interpretasi seseorang. 
Interasionime simbolik tidak lepas dari komunikasi dan simbol, kehidupan gay di Palembang tidak lepas dari keduanya. Beberapa gay dalam pandangan BP menunjukan orientasi seksualnya lewat bentuk tubuh dan gaya tata busana yang modis. Seseorang gay menunjukan diri mereka yang bersih dengan tubuh yang berotot, mengenakan busana yang memamerkan bentuk tubuh mereka adalah salah satu cara untuk menarik perhatian gay lainnya. Layaknya perempuan, gay laki-laki juga kerap melakukan perawatan diri seperti ke salon dan perawatan tubuh lainnya.

Homophobia merupakan ancaman bagi gay di Palembang. Sikap seseorang kadang di tentukan oleh respons orang lain terhadap diri kita dan kita bertindak sebagai diri, yang merupakan cerminan diri kita atas perilaku orang lain. Dalam prespektif interaksionisme simbolik konsep diri merupakan suatu etitas yang dinamis dan berubah-ubah sepanjang waktu sesuai kondisi yang di hadapi seseorang. Seseorang dapat stabil dengan orientasi seksual dirinya akan tetapi dapat berubah ketika usia bertambah, tekan dari lingkungan keluarga seperti menikah, dan juga homophobia yang dari masyarakat memengaruhi diri untuk bersikap.

Subjek penelitian juga kerap berbohong untuk meyakinkan keluarganya bahwa ia adalah seseorang yang normal dengan mentupi diri sebenarnya. Gay belum mendapatkan tempat di dalam masyarakat kita, meskipun kita ada di antaranya dapat menerima kehadiran homoseksual. BP menghindari atribut gay pada dirinya untuk menyembunyikan identitas diri dari keluarga dan gay lainnya. Sikap subjek penelitian yang introvet adalah cara untuk memanipulasi keadaan diri terhadap orang lain dan hanya terlihat sikap baik BP dimata orang lain dan dapat diterima dalam lingkungan sosialnya. Subjek penelitian lebih nyaman menjadi gay, kehidupan gaynya sama seperti kehidupan heteroseksual pada umumnya. Keinginan seperti menikah, diakui di masyarakat dan dapat tinggal bersama pasangan sesama jenis tanpa adanya diskriminasi dari masyarakat.

Untuk melihat kehidupan seorang gay dapat ditinjau dari kehidupan sosial yang mereka jalani, hal itu dapat berkaitan dengan kehidupan di dalam keluarga, kehidupan dengan teman, lingkungan pekerjaan, lingkungan sosial sekitarnya dan tentunya dengan pasangan sejenisnya. Untuk menjalani kehidupan seorang gay di Palembang penempatan diri juga tergantung dengan pemaknaan masing-masing individu dengan situasi yang dihadapi, setelah itu mereka dapat menterjemahkan sesuai dengan pemahaman masing-masing dan meresponsnya sebagai suatu tindakan, dan tindakan itu pula sebagai penggambaran diri oleh orang lain terhadap seseorang.

Gay di Palembang memaknai orientasi seksualnya bersifat kodrati meskipun mereka memahami bahwa orientasi seksual gay dianggap menyimpang, tidak normal dan penyakit. Mereka juga mengidentifikasi dirinya berbeda dari waria karena mereka adalah orang yang menyukai sesama jenis dan tidak menghilangkan identitas maskulin mereka. Berbeda dengan waria yang melakukan transformasi tubuh. Lebih lanjut, gay di Pelembang merasa waria dan lesbian lebih diterima daripada gay.] 


\section{Daftar Pustaka}

Adriani, Shintia, Arifa I. Anggai, dan Retno A. Pradoponingrum. 2017. "Pengungkapan Diri Gay kepada Keluarga." Psikosains (Jurnal Penelitian dan Pemikiran Psikologi) 12(1):1-8.

Ahmadi, Dadi. 2008. "Interaksi Simbolik: Suatu Pengantar." Mediator: Jurnal Komunikasi 9(2):301-16.

Arifin, Bambang Syamsul. 2015. Psikologi Sosial. Bandung: Pustaka Setia.

Boellstorff, Tom. 2010. "Antara Agama dan Hasrat: Muslim yang Gay di Indonesia." Jurnal Gandrung: Kajian Seksualitas Kritis 1(1):67-108.

Boellstorff, Tom. 2016. "Against State Straightism: Five Principles for Including LGBT Indonesians." E-International Relations. Diambil (https://www.e-ir.info/2016/03/ 21/against-state-straightism-fiveprinciples-for-including-lgbtindonesians/).

Cho, Catherine. 2019. “Indonesia's 'Fresh Meat': LGBTQ Activism Amid Political Homophobia and Transphobia." Independent Study Project (ISP) Collection 3170.

Cramer, David W. dan Arthur J. Roach. 1988. "Coming out to Mom and Dad: A study of Gay Males and Their Relationships with Their Parents." Journal of Homosexuality 15(3-4):79-92.

Demartoto, Agyo. 2010. "Konsep Maskulinitas dari Jaman ke Jaman dan Citranya dalam Media."

Denzin, Norman K. dan Yvonna S. Lincoln, ed. 2009. Handbook of Qualitatif Reseserch. Yogyakarta: Penerbit Pustaka Pelajar.
Diniati, Anisa. 2018. "Konstruksi Sosial melalui Komunikasi Intrapribadi Mahasiswa Gay di Kota Bandung." Jurnal Kajian Komunikasi 6(2):147-59.

Haryanto, Deny dan G. Edwi Nugrohadi. 2011. Pengantar Sosiologi Dasar. Jakarta: Prestasi Pustaka.

Khanis, Suvianita. 2013. "Human Rights and the LGBTI Movement in Indonesia." Asian Journal of Women's Studies 19(1):127-38.

Lewis, Oscar. 2016. Kisah Lima Keluarga: Telaahtelaah Kasus Orang Meksiko dalam Kebudayaan Kemiskinan. Jakarta: Yayasan Putaka Obor Indonesia.

Marching, Soe Tjen. 2010. “Editorial." Jurnal Gandrung: Kajian Seksualitas Kritis 1(2):4-6.

Polymenopoulou, Eleni. 2018. "LGBTI Rights in Indonesia: A Human Rights Perspective." Asia-Pacific Journal on Human Rights and the Law 19(1):27-44.

Pranata, Tommy Dwi. 2015. "Perilaku dan Realitas Sosial Kehiduppan Gay di Kota Samarinda." eJournal Sosiatri-Sosiologi 3(3):135-50.

Ritzer, George. 2009. Sosiologi Ilmu Pengetahuan Berparadigma Ganda. Jakarta: Rajawali Pers.

Ritzer, George dan Goodman J. Douglas. 2011. Teori Sosiologi Modern. Jakarta: Kencana Predana Media Group.

Satya Yoga, Dyah, Ni Wayan Suarmini, dan Suto Prabowo. 2015. "Peran Keluarga Sangat Penting dalam Pendidikan Mental, Karakter Anak serta Budi Pekerti Anak." Jurnal Sosial Humaniora 8(1):46-54.

Soyomukti, Nuarani. 2010. Pengantar Sosiologi: Dasar Analisis, Teori \& Pendekatan Menuju Analisis Masalah-masalah Sosial, Perubah- 
Bayu Irawati RM, Nur Hasyim

an Sosial \& Kajian Strategis. Yogyakarta: Ar-Ruzz Media.

Tim Liputan Sriwijaya Post. 2013. "Demam Cinta Sejenis di FB." Sriwijaya Post, Desember 22.
UNDP dan USAID. 2014. Laporan LGBT Nasional Indonesia - Hidup sebagai LGBT di Asia. 